detailed scientific experiments, is misleading, and is not conducive to the progress of science. In my papers on the subject of detoxicated vaccines detailed and extensive researches are mentioned, from which it is clearly proved that the detoxication process does not destroy the antigenic nature of the vaccine. Moreover, all other statements which have been made in $\mathrm{my}$ papers on the subject have been supported by extensive clinical and laboratory experiments carried out in a careful and scientific manner.

Dr. Pratt-Johnson is entitled to his opinions, and as such they are of value. When, however, they are published in a manner which would lead the reader to believe that they are authoritative facts, it seems to me that he is unfair to himself, to the work which he condemns, and unfair and misleading to the medical reader of his otherwise commendable paper. I am, Sir, yours faithfully,

Harley-street, W., Oct. 7 th, 1922 David Thomson.

\section{AN UNUSUAL EYE INJURY.}

\section{To the Editor of THE LANCET.}

SrR,-The following eye injury happening in a cotton mill may be of interest to your readers and probably more so to factory inspectors.

A girl was brought to me by the manager of a spinning mill with a "traveller" (i.e., a small brass alloy wire such as is used for binding books, \&c.) embedded firmly in the eye to the depth of a quarter of an inch, one part being in the iris and one in the cornea. These "travellers" are used on a vertical bobbin on a doubling machine travelling at 9000 pevolutions per minute, and this is, I understand, the first time an accident of this nature has occurred.

This patient, in my opinion, narrowly escaped being blinded, but after extraction nothing but a conjunctivitis followed, and this soon succumbed to a 5 per cent. solution of argyrol.

I am, Sir, yours faithfully,

R. KAY NIsBET, L.R.C.S. Edin. Hindley, Lanes., Oet. 6th, 1922.

\section{EFFECT OF POSITION IN THE FAMILY ON THE HEALTH OF THE CHILD. \\ To the Editor of THE LANCET.}

SIR,-In his article on this subject in THE LANCET of 0ct. 7th Dr. R. H. Vercoe has brought forward some very interesting data, but his omission from consideration of one vitally important factor absolutely invalidates his conclusions. He has omitted to consider the mortality figures for children according to their position in the family, and has investigated only children who have passed the age of 13 years. His figures show that in the group he investigated " in incidence of disease both past and present, the worst child is definitely the eldest, while the best is definitely the eighth child and upwards." This conclusion, which he presents without qualification, would naturally ke taken to apply to all children born. In reality it refers only to children who have not died before the cge of 13 .

The folowing mortality figures present the matter in a very different light :-

Arthur Geissler concluded from a study of about 26,000 births of unselected marriages among miners that the mortality of children was least in the four first born, and then increasec to a very high rate. Following are Geissler's figures (narriages with only one or two children are omitted) :

Chidren. $\begin{gathered}\begin{array}{c}\text { Perrentage of } \\
\text { deaths during } \\
\text { first year. }\end{array} \\
\text { Children. }\end{gathered} \quad$\begin{tabular}{c}
$\begin{array}{c}\text { Percentage of } \\
\text { deaths during } \\
\text { first year. }\end{array}$ \\
\hline
\end{tabular}
7 first year.

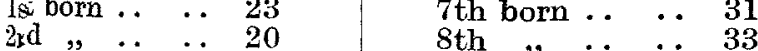

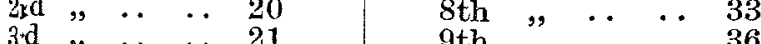

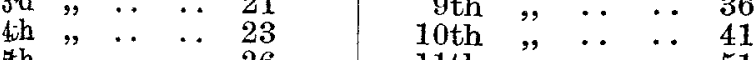

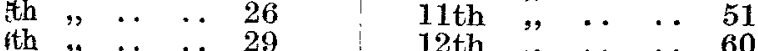

(No-Malthusianism and Race Hygiene, in "Problems in Eugnics," vol. ii., London, 1913. Dr. Alfred Ploetz, President of the Int soc for $\mathrm{R}$ ace $\mathrm{H}$, 1913.

The following table is based on the reproductive histories of 191 married mothers who had 5617 births. Miscarmiages

are not included. It was made in Jobnstown, Pa., U.S.A., in 1913.

Children.

1st and 2nd born

3rd and 4th

5 th and 6 th

7 th and 8th ,

9 th and later

(Infant Mortality. Emma Duke. 1915.)

Dr. Alice Hamilton, bacteriologist in the Memorial Institute for Infections Diseases, Chicago, published the results of a study of 1600 families in the neighbourhood in 1910. The number of children live-born was compared with the number of children who reached the age of 3 . A table calculated from the data of all the families shows an ascending mortality-rate.

Number in family.

4 children and less

6 ," , more

$7 \quad, \quad, \quad, \quad$,

$8 \quad, \%, \quad, "$,

(The Case for Birth Control. YVargaret H. Sanger. New York. 1917$.

I suggest that if Dr. Vercoe would investigate the child mortality statistics among the families whose children are included in his recent investigation, his conclusions would have to be very greatly modified. if not absolutely reversed.

I am, Sir, yours faithfully,

Harley-street, W., Oct. 9th, $1922 . \quad$ NoRMaN HAIRE.

\section{đIf Se Serbites.}

\section{NEW DIRECTOR-GENERAL OF THE INDIAN} MEDICAL SERVICE.

Col. R. C. Macwatt, C.I.E., Inspector-General of Civil Hospitals in the Punjab, has been appointed successor to Maj.-Gen. Sir W. R. Edwards, O.B., C.M.G., who retires shortly from the post of Director-General of the Indian Medical Service.

ROYAL NAVAL MEDICAL SERVICE.

Temp. Surg. Lt. (D.) E. C. Bevis to be Surg. Lt. (D.) with seniority.

ROYAL ARMY MEDICAL CORPS.

Temp. Capt. V. Vesselovsky relinquishes his commn. and is granted the rank of Maj.

Capt. G. R. Grant is seconded for service with the Egyptian Army.

ARMY RESERVE OF OFFICERS.

Maj.-Gen. J. J. Russell, late R.A.M.C., and Lt.-Col. K. R. Barnett, having attained the age limit of liability to recall cease to belong to the Res. of Off.

\section{INDIAN MEDICAL SERVICE.}

Majs. W. S. J. Shaw, H. H. Broome, D. Heron. H. C. Keates, L. Reynolds, R. A. Needham (temp. Lt.-Col.), Dwarka Prasad Goil, and J. Kirkwood to be Lt.-Cols. Capts. Phirozshah Byramji Bharucha, R. W. G. Hingston. R. C. Clifford, Latafat Husain Khan, R. de S. B. Herrick, Hargobind Lal Batra, H. Purvis (Bt. Maj.), and W. Walker to be Majs.

The King has approved the retirement of Col. T. M. Granger.

\section{ROYAL AIR FORCE}

Capt. J. J. Boyle, Army Dental Corps, is granted a temp commn. as a Flight Lt. on attachment for four years' duty with the R.A.F.

\section{ARMY DENTAL CORPS RESERVE.}

Vacancies are announced in the Army Dental Corps, Regular Army Reserve of Officers, for a limited number of dental surgeons who held temporary commissions as dental officers in the Army during the war of 1914-19. Appointments will be made in two classes: Class I., officers who are fit for general service; Class II., all other officers. An officer will not be appointed to a higher rank than that which he was granted on relinquishment of his temporary commission nor will he be granted a commission in the Reserve of Officers if his age exceeds: For a lieutenant. Class I., 30, Class II., 40 ; captain, 35 and 45 respectively and major, 40 and 45 respectively. Particulars of the conditions of service may be obtained from the Secretary (A.M.D. 1), War Office, Whitehall, S.W. 1. 